\title{
Sediment Carbon Variations in the Venice Lagoon and Other Transitional Water Systems of the Northern Adriatic Sea
}

\author{
Adriano Sfriso ${ }^{1, *(1)}$, Alessandro Buosi ${ }^{1}\left(\mathbb{D}\right.$, Yari Tomio ${ }^{1}$, Abdul-Salam Juhmani ${ }^{1}{ }^{1}$, \\ Stefania Chiesa ${ }^{2,3}$, Marta Greco ${ }^{2}$, Chiara Gazzola ${ }^{2}$, Michele Mistri ${ }^{4}$, Cristina Munari ${ }^{4}$ and \\ Andrea Augusto Sfriso 4 \\ 1 Department of Environmental Sciences, Informatics and Statistics (DAIS), University Ca' Foscari Venice, \\ Via Torino 155, 30170 Mestre (Ve), Italy; alessandro.buosi@unive.it (A.B.); yari.tomio@unive.it (Y.T.); \\ abdulsalam.juhmani@unive.it (A.-S.J.) \\ 2 Department of Molecular Sciences and Nanosystems (DSMN), University Ca' Foscari Venice, Via Torino 155, \\ 30170 Mestre (Ve), Italy; stefania.chiesa@unive.it (S.C.); 859944@stud.unive.it (M.G.); \\ kiaramx196@gmail.com (C.G.) \\ 3 Italian Institute for Environmental Protection and Research (ISPRA), Via Vitaliano Brancati 48, \\ 00144 Rome, Italy \\ 4 Department of Chemical and Pharmaceutical Sciences, University of Ferrara, Via Fossato di Mortara 17, \\ 44121 Ferrara, Italy; msm@unife.it (M.M.); mnc@unife.it (C.M.); sfrndr@unife.it (A.A.S.) \\ * Correspondence: sfrisoad@unive.it; Tel.: +39-041-234-8529
}

Received: 10 November 2020; Accepted: 4 December 2020; Published: 6 December 2020

\begin{abstract}
The concentrations of inorganic, organic and total carbon, and some sedimentary parameters (sediment density, fines, $\mathrm{pH}$, and shell fragments), have been analyzed in surface sediments of the Venice Lagoon since 1987. Environmental scenarios, characterized by different anthropogenic impacts, have been considered, especially in the central basin where more information is available. Data collected in 2009 in the lagoons and ponds of Po Delta, in Comacchio Valleys and Pialassa della Baiona have been also considered and analyzed together with those recorded in the whole Venice Lagoon in 2011. The results show a strong correlation of the inorganic carbon (Cinorg) with the carbonatic or siliceous origins of the sediments and changes of both Cinorg and organic carbon (Corg) according to different anthropogenic impacts, especially eutrophication and clam-fishing activities. Higher sediment density, grain-size, and $\mathrm{pH}$ were associated to good-high ecological conditions and the higher presence of inorganic carbon of biological origin (shell fragments and calcified macroalgal fragments). Conversely, Corg, which is associated to eutrophic conditions, was strongly affected by the sediment disturbance and the presence of high concentrations of bivalves which enhance its consumption.
\end{abstract}

Keywords: carbon concentrations; surface sediments; anthropogenic impacts; environment resilience; transitional environments; Venice Lagoon; Po Delta; Comacchio Valleys; Pialassa della Baiona

\section{Introduction}

Transitional Water Systems (TWS) are water bodies (lagoons, ponds, deltas, estuaries, fjords) with wide ecological features ranging from marine to freshwater conditions. They can be strongly affected by freshwater inputs (i.e., Po delta lagoons and ponds in Italy [1,2]), be almost completely devoid (i.e., Mar Menor in Spain [3]) or present intermediate conditions (i.e., Venice Lagoon, in Italy, [4]). TWS are under severe stress conditions from both natural and anthropogenic pressures that affect the ecological status and organism communities, including salinity [5]), nutrient/pollutant inputs [6,7], harboring [8], 
and fishing activities [9,10]. However, a high water renewal can strongly mitigate these impacts, triggering a rapid environmental recovery [7]. Changes of nutrients and carbon concentrations in surface sediments are the results of both human impacts and natural ecosystem resilience. When anthropogenic pressures reduced, the sedimentary system would recover, influencing the vegetation [11] and the benthic [12,13] and fish fauna $[14,15]$.

Despite the wide literature concerning nutrient [6,7,10], different pollutant concentration [16-18], and biota changes [12,13], the information on carbon concentrations is nowadays very scarce [17-19].

Therefore, the aims of the present study were mainly two: (i) to describe the spatial and temporal variations of carbon concentrations (total, inorganic, and organic) in the surface sediment of the Venice Lagoon since 1987 and (ii) to compare the data from the Venice Lagoon with those collected in other TWSs in the northern Adriatic Sea (Italy).

\section{Materials and Methods}

\subsection{Description of Study Areas and Sampling Campaigns}

The Venice Lagoon, located in the north-western Adriatic Sea, is the most studied TWS of the Mediterranean Sea. It covers an area of ca. $549 \mathrm{~km}^{2}$ accounting for ca. $39 \%$ of the total Italian TWSs [11] and has a water surface of ca. $432 \mathrm{~km}^{2}$ (Figure 1).

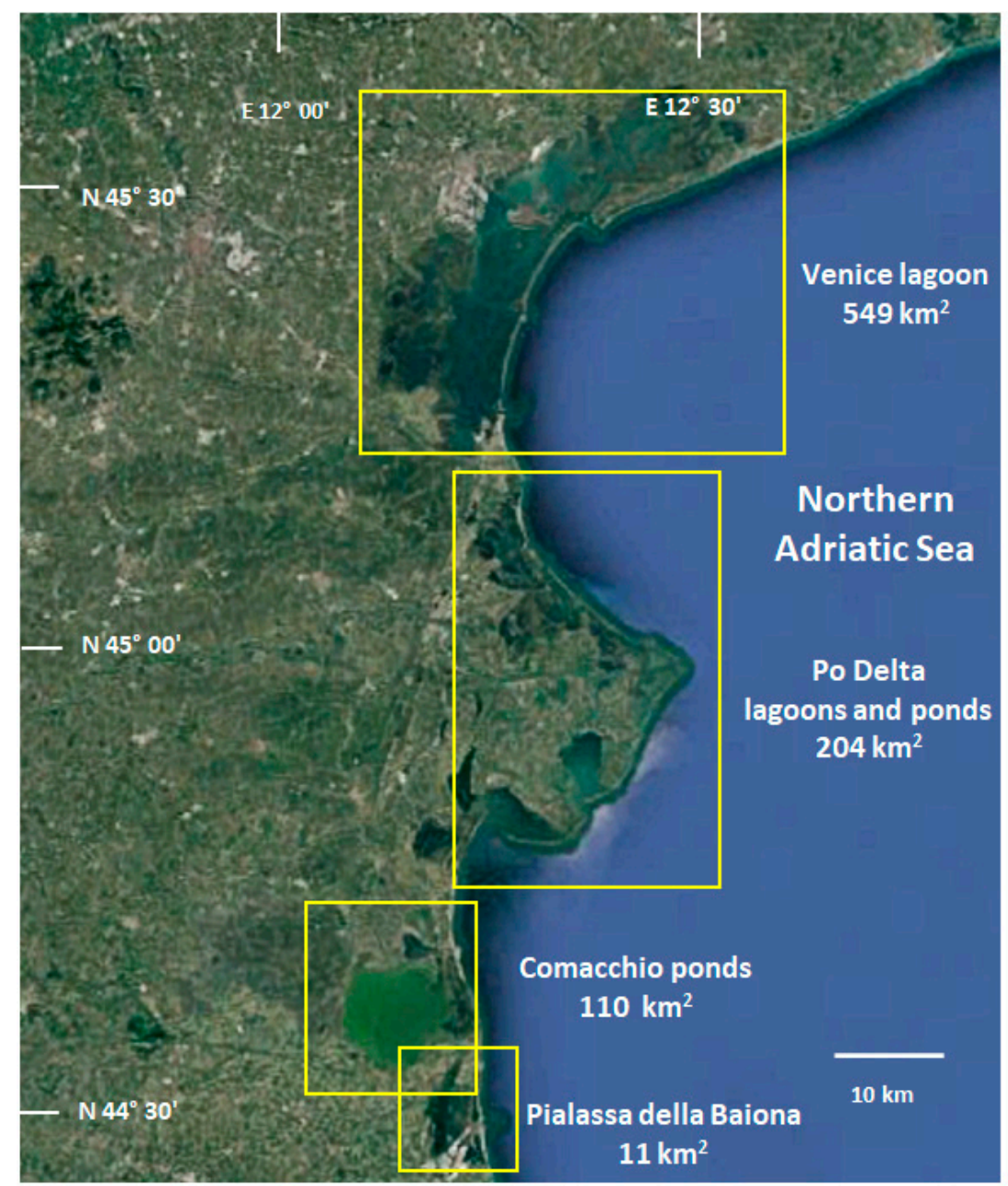

Figure 1. Main Transitional Water Systems (TWS) of the North-western Adriatic Sea.

The mean depth of the Venice Lagoon is ca. $1.2 \mathrm{~m}$ on the mean tide level: it reaches $15-20 \mathrm{~m}$ in the canals, $1-2.5 \mathrm{~m}$ in the water bodies and a few centimeters in the shallower areas. Water circulation in 
the Venice Lagoon is mainly driven by tidal action [19] which enables the renewal of about $60 \%$ of the total lagoon water every $12 \mathrm{~h}$ [20]. Residence time varies over the lagoon and with meteorological conditions, with average values ranging from few days, in the areas close to the inlets, to 40 days in the inner, chocked areas [21].

Morphological barriers (Malamocco-Marghera canal at South, and the salt marshes of Burano and Torcello at North) divide the lagoon into three basins differing from the hydrological ones whose watersheds shift according to tides and winds. The Venice Lagoon is also characterized by strong marine conditions resulted from the high water exchange (ca 19,000 $\mathrm{m}^{3} \mathrm{~s}^{-1}$ ) with the sea, in comparison with negligible freshwater inputs of $34.5 \mathrm{~m}^{3} \mathrm{~s}^{-1}$ [22].

Since 2003, the research team at the Marine Ecology Lab, Ca' Foscari University of Venice (Italy) has collected data on the Carbon of the superficial sediments in the entire lagoon. Sampling campaigns were carried out in 2003 (165 stations), 2011 (118 stations), 2014 and 2018 (88 stations), and in the late spring-early summer period. In this paper, the concentrations recorded in 85 common stations have been analyzed and compared.

In addition, for the central lagoon $\left(132 \mathrm{~km}^{2}\right)$, carbon mapping dates back to 1987 (35 stations) and was repeated in 1993, 1998, 2003, 2011, 2014, and 2018. This wide temporal scale allowed us to analyze the carbon concentrations in the various events that have characterized the lagoon over the last 40 years: the macroalgal dominance (1987) [4,23]; the macroalgal decline (1993) [24]; the intense Manila clam (Ruditapes philippinarum Adams Reeve) fishing activities (1998-2003) [10]; the clam-fishing decline (2011) [7]; and the reduction of anthropogenic impacts and the beginning of the lagoon environmental recovery (2014-2018) [7].

The Po Delta includes a wide water surface (ca. $204 \mathrm{~km}^{2}$ ) divided into many lagoons and ponds with depth ranging from 0.5 to $2.5 \mathrm{~m}$, according to the water body. Salinity is very variable depending on the proximity and flow of the river mouths. Hard substrata are rare and mainly represented by some oyster beds scattered on the bottoms or stone embankments. Clam-farming and clam-fishing activities, unlike the Venice Lagoon where they declined sharply [7], are the main resources of the basins, resulting in high sediment resuspension with severe environmental consequences. The main primary producer of Po Delta is phytoplankton, whereas the free-floating nitrophilic macroalgae, especially Ulvaceae, Gracilariaceae, and Solieriaceae dominate the areas with lower anthropogenic impact. The beds of the aquatic angiosperm Ruppia cirrhosa (Petagna) Grande present until the 1990s has now completely disappeared [25]. The ecological conditions were ranging from poor to bad [25]. For these lagoons, there is little information and these are the only data available for the carbon species. Samples of surface sediments were collected in 2009 in 20 stations (3 at Caleri, 2 at Marinetta, 2 at Vallona, 3 at Barbamarco, 3 at Canarin, 4 at Scardovari, and 3 at Goro) during late spring-early summer period.

The Comacchio Valleys are a complex of shallow coastal ponds of approximately $110 \mathrm{~km}^{2}$ which have slight exchange with the sea through two small channels. The freshwater input from the Reno River and the consequence of anthropogenic impacts like eel farming resulted in the shift of the ecological status from good ecological conditions dominated by aquatic angiosperms and macroalgae of high ecological value to a degraded and homogeneous basin dominated by phytoplankton and picocyanobacterial blooms of poor status ([26] and references therein). Contrary to the other TWS studied in this paper, water exchange with the sea is completely negligible and does not allow an improvement in the ecological status. Regarding surface sediments, no other carbon species information is available for this environment. Due to the homogeneity of the ecological conditions present throughout the basin, in 2009, samples of surface sediments were only collected in two stations during late spring-early summer period.

The Pialassa della Baiona pond is a shallow basin (mean depth: $60 \mathrm{~cm}$ ) of approximately $11 \mathrm{~km}^{2}$ connected with the Adriatic Sea through an artificial canal linked to the Ravenna harbor. Freshwater inputs, coming from a network of channels draining an intensively cultivated area, are negligible. The basin is colonized by abundant populations of macroalgae, especially the non-indigenous species 
Agarophyton vermiculophyllum (Ohmi) Gurgel, J.N. Norris et Fredericq [27], and the ecological status is poor [28]. Moreover, this TWS has been little studied and no other information is available. Samples of surface sediments were collected in 2009 in three stations during late spring-early summer period.

\subsection{Carbon Determination in Sediment}

The top $5 \mathrm{~cm}$ sediment layer was sampled by a Plexiglas corer (i.e., $10 \mathrm{~cm}$ ). Three subsamples were collected in each station and mixed together. One subsample was retained for carbon analyses and another for the determination of the sediment grain-size and density. Both subsamples were stored at $-20{ }^{\circ} \mathrm{C}$ until the laboratory analyses.

Freeze-dried sediment samples were pulverized using a sediment mill (Fritsch Pulverisette, Idar-Oberstein, Germany). The concentration of total carbon (Ctot) was measured by a CHNS Analyzer (Vario-MICRO, Elementar CHNS, Thermo Fisher Scientific Inc., Milano, Italy) whereas inorganic carbon (Cinorg) was determined after samples combustion at $440{ }^{\circ} \mathrm{C}$ for $2 \mathrm{~h}$ [29] in order to eliminate most of the organic matter with negligible loss of carbonates [30]. Organic carbon (Corg) was determined by difference. All analyses were performed in duplicate in two different days in order to obtain an accuracy $>95 \%$. The quality and accuracy of quantitative analyses were assured by analyzing a certified reference material (Soil standard Ah, Carbon concentration: $7.44 \% \pm 0.1$ ) obtained from the National Institution of Standards and Technology NIST (USA). For sediments with high carbonate content $(50-70 \%)$ as those present in the Venice Lagoon, heat combustion $\left(440^{\circ} \mathrm{C}\right)$ resulted to yield the closest measured concentrations of carbon, compared to those obtained with the acidification method described previously [31]. Both methods are affected by systematic errors arising from the elimination of Corg and Cinorg, but the combustion method is preferable, because the acidified samples may result in damaging of some parts of the CHNS-Analyzer. The concentrations of the carbon species were reported in $\mathrm{mg}$ DWT $\mathrm{cm}^{-3}$ after normalization with the sediment amount per surface unity (dry sediment density). Non-normalized data, expressed in $\mathrm{mg} \mathrm{g}^{-1} \mathrm{dwt}$, are reported in Tables S1 and S2 in the Supplementary Material.

\subsection{Sediment Characteristic Determination}

The determination of the $\mathrm{pH}$ (accuracy \pm 0.015 units) of surface sediments $(5 \mathrm{~cm}$ sediment top layer) was determined in field using a portable $\mathrm{pH}$-meter ( $\mathrm{pH}$ meter PH25 + CRISON). Dry sediment density ( $\mathrm{g}$ DWT $\mathrm{cm}^{-3}$ ) was determined in laboratory by sediment desiccation at $110{ }^{\circ} \mathrm{C}$ in tared crucibles of 20-30 mL. The percentage of fines (fraction $<63 \mu \mathrm{m}$ ) was obtained by wet sieving ca. $50 \mathrm{~g}$ of dried sediment throughout Endecotts sieves (ENCO Scientific Equipment, Spinea (Venice), Italy). All analyses were performed in duplicate. The amount of shell fragments was determined by sieving the dry sediment throughout a sieve of $1 \mathrm{~mm}$ before sediment grinding.

\subsection{Statistical Analyses}

One-way analysis of variance (ANOVA) was applied to test differences of sediment parameter in different monitoring periods. Differences were considered significant when $p<0.05$. Prior to the analyses, the distribution of each variable was checked for normality and homogeneity of variance by the Kolmogorov-Smirnov test $(p<0.05)$. Non-parametric Spearman's coefficients $(p<0.05)$ highlighted the correlations among environmental parameters using STATISTICA 7.1 (StatSoft srl). The principal component analysis (PCA) analyzed the multivariate patterns of the matrix of 113 cases (stations) in response to the independent variables (shell fraction, sediment density, fines, inorganic, and organic carbon concentrations). Besides, the PCA transposed matrix was created to compare the relationship among the stations of the Venice Lagoon, the Po Delta, Comacchio Valleys, and Pialassa della Baiona. 


\section{Results}

\subsection{Carbon Determination and Sediment Characteristics}

The mean values of the carbon species (Ctot, Cinorg, Corg) concentrations and the superficial sediment parameters collected in the studied TWS are reported in Figure 2 and Table S1 in Supplementary Material. Total carbon was almost five times higher $\left(72.3 \mathrm{mg} \mathrm{cm}^{-3} \mathrm{dwt}\right)$ in the Venice Lagoon than in the other TWSs (14.5-16.2 $\left.\mathrm{mg} \mathrm{cm}^{-3} \mathrm{dwt}\right)$, mainly due to the highest Cinorg concentration $\left(59.4 \mathrm{mg} \mathrm{cm}^{-3} \mathrm{dwt}\right)$. Similarly, in the Venice Lagoon, Corg $\left(12.9 \mathrm{mg} \mathrm{cm}^{-3} \mathrm{dwt}\right)$ was also markedly higher than in the other TWSs, with concentrations more than 2 times higher than those of the Po Delta $\left(5.8 \mathrm{mg} \mathrm{cm}^{-3} \mathrm{dwt}\right)$ and 46-55\% higher than the concentrations in Pialassa della Baiona and Comacchio Valleys, respectively.

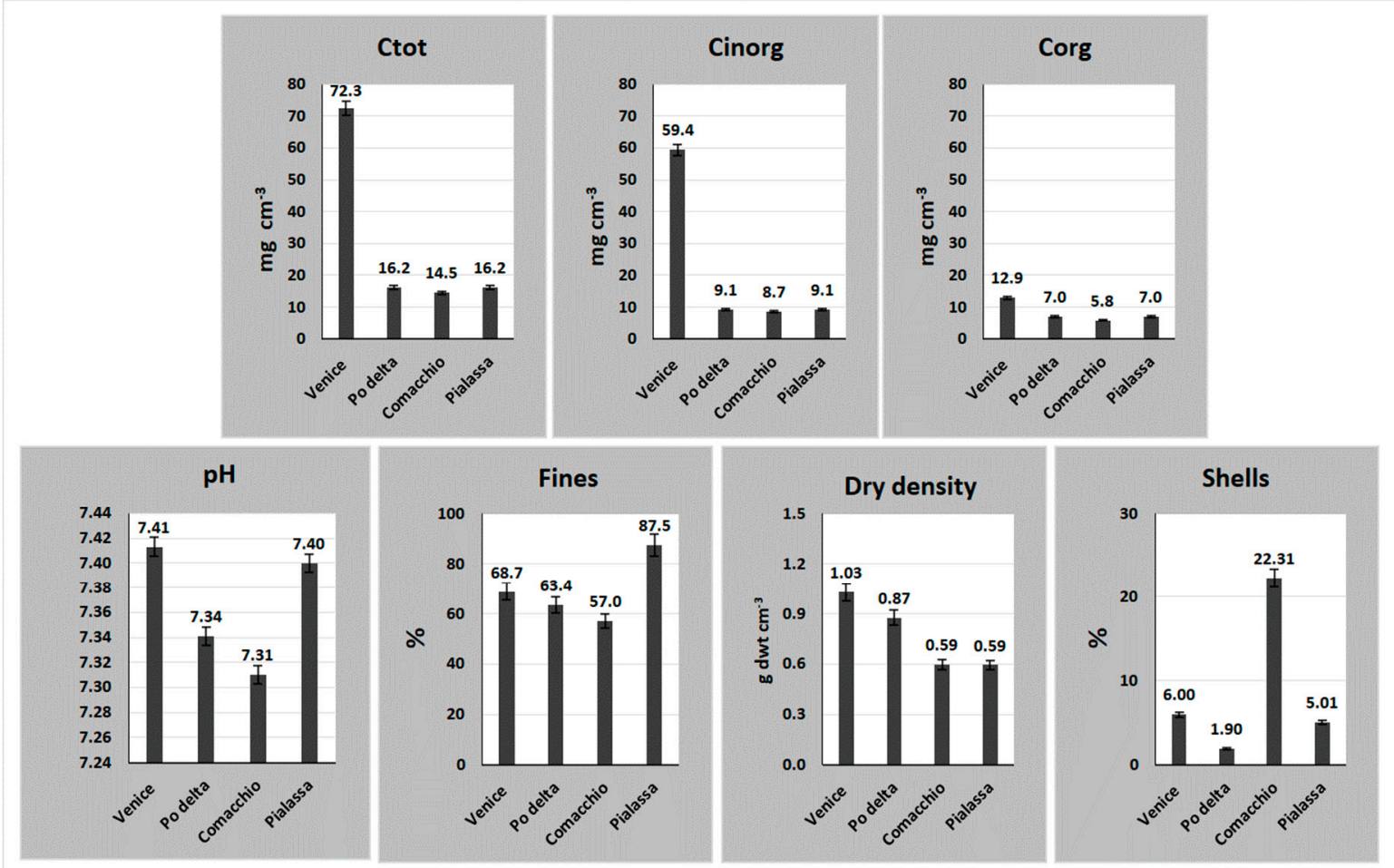

Figure 2. Average values of the carbon species (Ctot, Cinorg, Corg) and sediment parameters ( $\mathrm{pH}$, fines, dry density, shell fragments) in the studied TWSs.

The average $\mathrm{pH}$ values of superficial sediments of the Venice Lagoon and Pialassa della Baiona were similar (7.41-7.40), whereas the lower mean value was recorded in the Comacchio Valleys (7.31) (Figure 2). This was strictly related to the lower percentage of fines (57\%) and sediment dry density

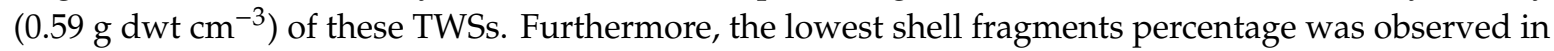
the Po Delta lagoons and ponds $(1.90 \%)$, while the highest percentage was detected in the Comacchio Valleys (22.3\%) (Figure 2).

\subsection{Carbon Variations in the Venice Lagoon (2003-2018)}

The concentrations of the carbon species (Ctot, Cinorg, Corg) in surface sediments of the whole Venice Lagoon were recorded in different periods (2003; 2011; 2014 and 2018) (Figure 3 and Table S2 in Supplementary Material). 

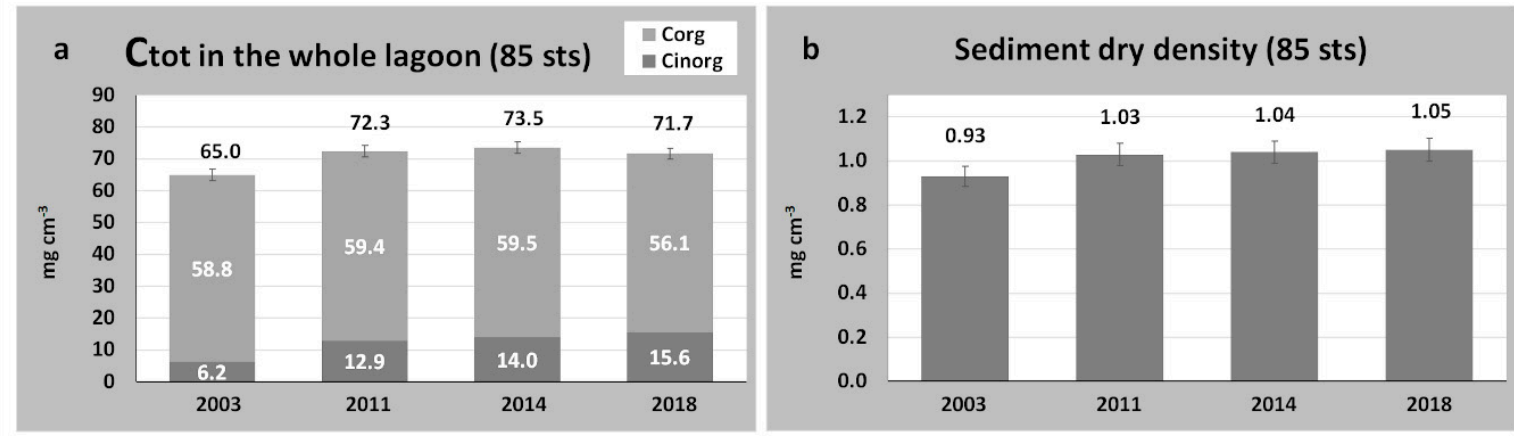

Figure 3. (a) Average values of the carbon concentrations recorded in the surface sediments (85 stations) of the whole Venice Lagoon. Data were normalized taking into account the amount of dry sediment (dry density) for volume unit (b) and expressed in $\mathrm{mg}$ dw $\mathrm{cm}^{-3}$.

The average Corg concentrations (Figure 3a) showed an increasing trend from 2003 (6.2 $\mathrm{mg} \mathrm{dwt}$ $\left.\mathrm{cm}^{-3}\right)$ during the intense clam-fishing activities to $2018\left(15.6 \mathrm{mg} \mathrm{dwt} \mathrm{cm}^{-3}\right)$ when these activities were negligible.

The mean Corg difference contributed significantly to increase the average concentration of Ctot that changed from $65 \mathrm{mg} \mathrm{dwt} \mathrm{cm}{ }^{-3}$ (2003) to $71.7 \mathrm{mg} \mathrm{dwt} \mathrm{cm}^{-3}$ (2018). Indeed, the concentrations of Cinorg were quite similar, ranging from 56.1 to $59.5 \mathrm{mg} \mathrm{cm}^{3}$. In parallel, sediment density (Figure 3b) increased from 0.93 to $1.05 \mathrm{mg} \mathrm{cm}^{-3}$ with loss of the fine fraction.

The difference of Corg among the considered years was highly significant (one-way ANOVA) between 2003 and the other years: 2011, 2014, and $2018(p<0.001$, Table 1). A significant difference $(p<0.05)$ was also recorded between Corg of 2011 and 2018. Significant differences were obtained for Ctot between 2003-2011 and 2003-2014; whereas, no significant differences occurred between Cinorg among all sampling years.

Table 1. One-way ANOVA analysis between the different sampling periods; n.s.: not significant values.

\begin{tabular}{|c|c|c|c|}
\hline \multicolumn{4}{|c|}{ One-Way ANOVA } \\
\hline & Ctot & Cinorg & Corg \\
\hline $2003-2011$ & $p<0.050$ & n.s. & $p<3.26 \times 10^{-15}$ \\
\hline 2003-2014 & $p<0.025$ & n.s. & $p<7.10 \times 10^{-18}$ \\
\hline 2003-2018 & n.s. & n.s. & $p<2.10 \times 10^{-14}$ \\
\hline 2011-2014 & n.s. & n.s. & n.s. \\
\hline 2011-2018 & n.s. & n.s. & $p<0.029$ \\
\hline 2014-2018 & n.s. & n.s. & n.s. \\
\hline
\end{tabular}

The carbon distribution maps reported in Figure 4 show that the highest Ctot concentrations were recorded in the central and northern basins around the historical centre of Venice, the watershed of Lido Island, and the salt marshes of Burano and Torcello. Conversely, Corg showed the maximum concentrations close to the saltmarshes of the southern lagoon and in the extreme northern lagoon. It is noteworthy observing that Corg intervals represented in Figure 4 for 2003 are considerably lower than others, otherwise no differences could have been appreciated in the map.

The measurements of carbon in the central part of the Venice Lagoon referred to recent years (2003-2018) were then merged with three additional previous campaigns, carried out in 1987, 1993, and 1998 (Figure 5 and Table S3 in Supplementary Material). 


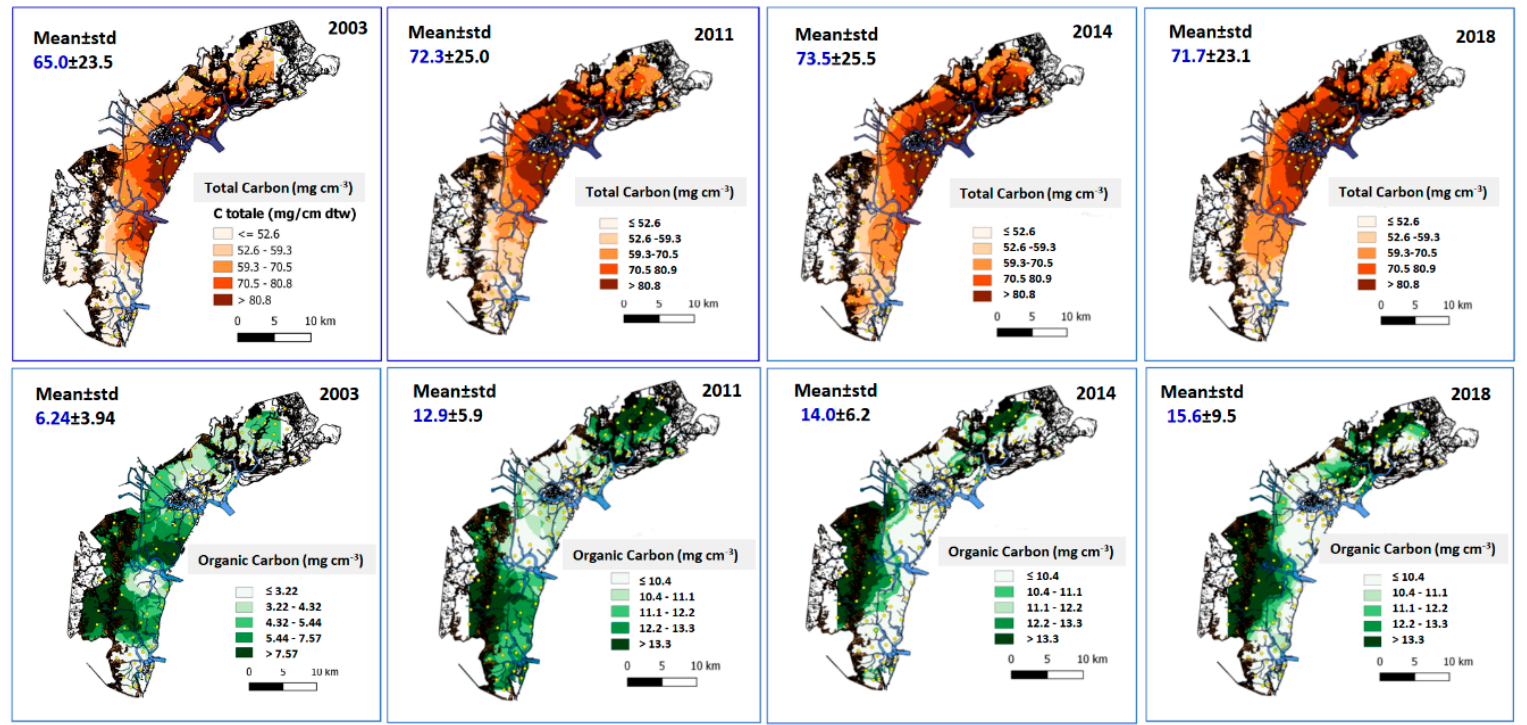

Figure 4. Distribution maps of Ctot and Corg in the surface sediments of the whole Venice Lagoon.
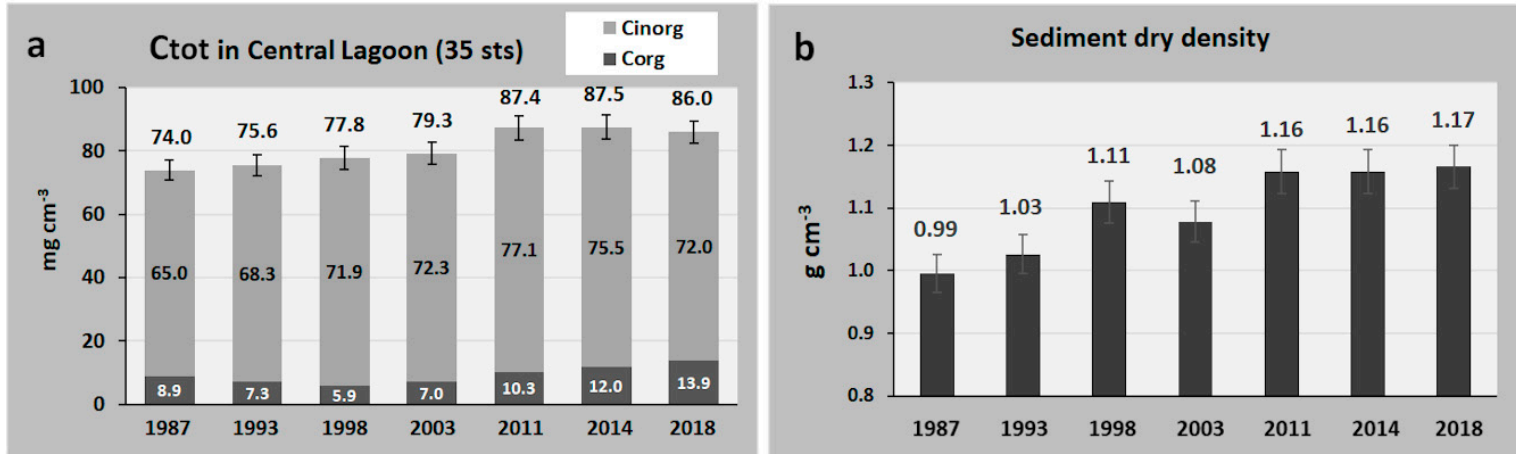

Figure 5. (a) Average values of the carbon concentrations recorded in the surface sediments (35 stations) of the central Venice Lagoon during different periods. (b) Amount of dry sediment (dry density) for volume unit.

In 1987, Ctot and Corg concentrations were 74.0 and $8.9 \mathrm{mg} \mathrm{dwt} \mathrm{cm}^{-3}$, respectively. Organic carbon dropped to $5.9 \mathrm{mg} \mathrm{cm}^{-3}$ in 1998, whereas, in the following years, it increased to up to $13.9 \mathrm{mg} \mathrm{cm}^{-3}$ in 2018 (Figure 5a). Since 2011, Corg increased significantly, whereas Ctot ranged between 86.0 and $87.5 \mathrm{mg} \mathrm{dwt} \mathrm{cm}^{-3}$. The dry density of surface sediments (Figure $5 \mathrm{~b}$ ) followed the same trend of Ctot increasing from 1987 to 2018, due to the loss of the fine fraction.

The analysis of variance (one-way ANOVA) revealed that Corg concentrations were significantly different $(p<0.05 ; p<0.001)$ during the majority of the sampling periods (Table 2$)$, whereas no significant differences were recorded for Ctot and Cinorg, except the significant difference between 1987 and 2011 for the Cinorg concentration.

\subsection{Carbon Variations in all TWSs}

The statistical analysis (non-parametric Spearman's coefficients) between the stations of all the considered TWSs showed a high number of positive and inverse correlations between the carbon species and the considered parameters and between the same environmental parameters (Table 3). Among them, the negative correlations between fines and dry density $(\mathrm{r} \leq-0.65)$ and fines and $\mathrm{pH}$ $(\mathrm{r} \leq-0.59)$ and the positive correlations between dry density and $\mathrm{pH}(\mathrm{r} \leq 0.53)$ and dry density and Cinorg $(\mathrm{r} \leq 0.53)$ are particularly relevant. 
Table 2. Statistical correlations ( $p$-value) between carbon species (Ctot, Corg and Cinorg) during different sampling periods in the central part of the Venice Lagoon; n.s.: not significant.

\begin{tabular}{lllc}
\hline \multicolumn{3}{c}{ One-Way ANOVA } \\
\hline & Ctot & Cinorg & Corg \\
\hline $1987-1993$ & n.s. & n.s. & 0.042 \\
$1987-1998$ & n.s. & n.s. & $2.49 \times 10^{-4}$ \\
$1987-2003$ & n.s. & n.s. & 0.026 \\
$1987-2011$ & n.s. & 0.041 & n.s. \\
$1987-2014$ & n.s. & n.s. & $3.13 \times 10^{-4}$ \\
$1987-2018$ & n.s. & n.s. & $3.69 \times 10^{-6}$ \\
\hline $1993-1998$ & n.s. & n.s. & n.s. \\
$1993-2003$ & n.s. & n.s. & n.s. \\
$1993-2011$ & n.s. & n.s. & $8.59 \times 10^{-4}$ \\
$1993-2014$ & n.s. & n.s. & $1.98 \times 10^{-7}$ \\
$1993-2018$ & n.s. & n.s. & $6.14 \times 10^{-9}$ \\
\hline $1998-2003$ & n.s. & n.s. & n.s. \\
$1998-2011$ & n.s. & n.s. & $2.10 \times 10^{-6}$ \\
$1998-2014$ & n.s. & n.s. & $7.84 \times 10^{-11}$ \\
$1998-2018$ & n.s. & n.s. & $1.14 \times 10^{-11}$ \\
\hline $2003-2011$ & n.s. & n.s. & $5.42 \times 10^{-4}$ \\
$2003-2014$ & n.s. & n.s. & $4.08 \times 10^{-7}$ \\
$2003-2018$ & n.s. & n.s. & $4.70 \times 10^{-9}$ \\
\hline $2011-2014$ & n.s. & n.s. & n.s. \\
$2011-2018$ & n.s. & n.s. & $8.03 \times 10^{-4}$ \\
\hline $2014-2018$ & n.s. & n.s. & n.s \\
\hline & & & \\
\hline
\end{tabular}

Table 3. Non-parametric Spearman's coefficients between carbon compounds and some parameters of surface sediments of all the considered lagoons and ponds. In red, significant values: $p<0.05$ for $r \geq 0.19$.

\begin{tabular}{cccccccc}
\hline \multicolumn{7}{c}{ Spearman's Non-Parametric Coefficients } \\
\hline \multicolumn{7}{c}{$p<\mathbf{0 . 0 5}$ per $\mathbf{r} \geq \mathbf{0 . 1 9}$} \\
\hline $\mathbf{p H}$ & Fines & Shells & Dry Density & Corg & Cinorg & Ctot \\
\hline pH & 1.00 & & & & & & \\
Fines & -0.59 & -0.59 & & & & & \\
Shells & 0.27 & -0.34 & 1.00 & & & & \\
Dry density & 0.53 & -0.65 & 0.07 & 1.00 & & & \\
Corg & -0.25 & 0.32 & 0.26 & -0.42 & 1.00 & & \\
Cinorg & 0.19 & -0.04 & 0.26 & 0.45 & 0.05 & 1.00 & \\
Ctot & 0.01 & 0.08 & 0.31 & 0.20 & 0.35 & 0.85 & 1.00 \\
\hline
\end{tabular}

The principal component analysis (PCA) of the first two components applied to the whole stations sampled in 2009 in the Po Delta, Comacchio Valleys, and Pialassa della Baiona, and in 2011, the closest date of those sampled in Venice Lagoon, are shown in Figure 6a. The first two components explained the $61.1 \%$ of the total variance and the four sediment parameters, namely: $\mathrm{pH}$, dry density, fines, and shell fragments showed a loading $>0.7$. The explained variance increased to $79.6 \%$ by considering three components. In addition, PCA highlighted the affinity among parameters confirming the results of the correlations coefficients: $\mathrm{pH}$ and the sediment density were associated to the concentration of Cinorg and the presence of shell fragments, whereas Corg was clustered in the same side of fines. 

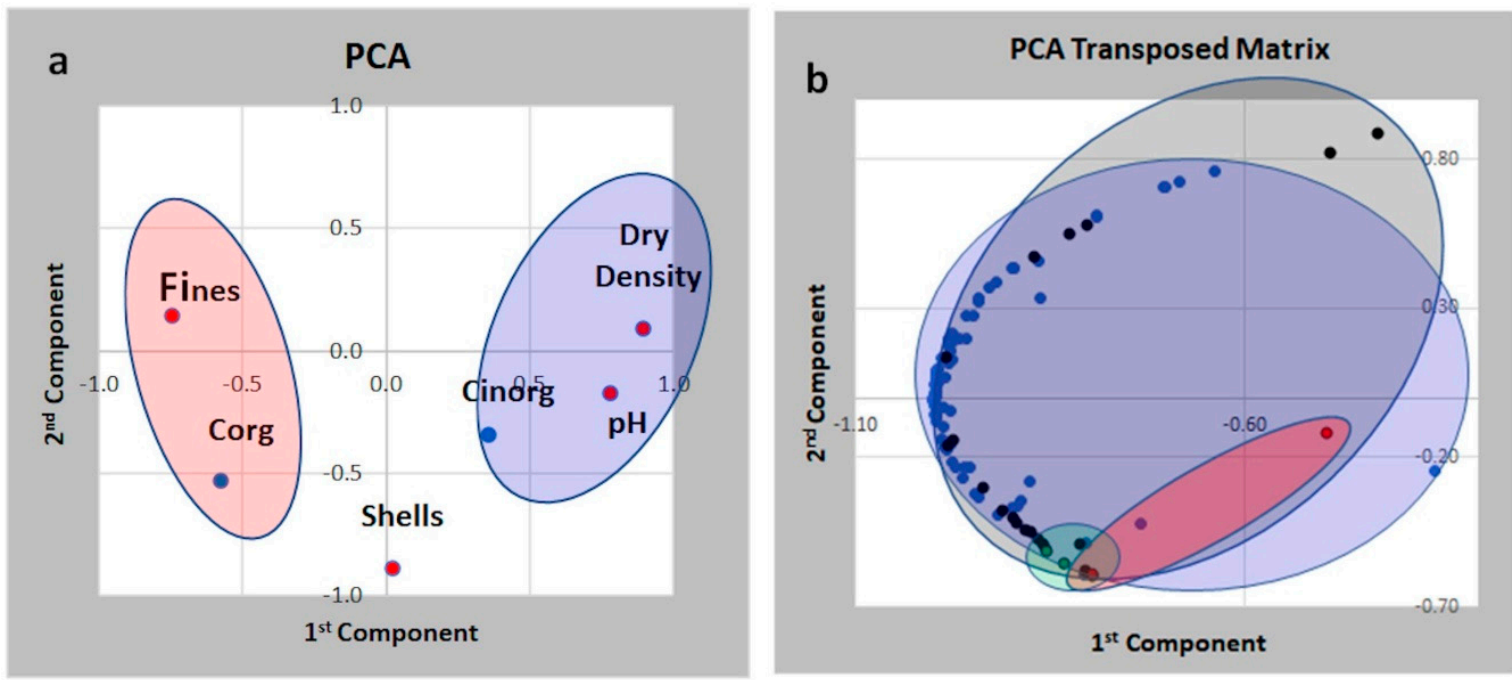

Figure 6. (a) Principal component analysis (PCA) among carbon species and surface sediment characteristics. Red small circles represent values of loading $>0.7$. Large circles show the different parameters clustering associated to bad (red) or good (blue) ecological conditions. (b) PCA of the transposed matrix to highlight the station associations. The different colors show different TWSs. In blue: Venice Lagoon; in black: lagoons and ponds of the Po Delta; in green: Pialassa della Baiona; in red: Comacchio Valleys.

The PCA of the transposed matrix applied to the same parameters and stations (Figure $6 \mathrm{~b}$ ) shows the clustering among the stations of the different TWSs. All the stations of the Venice Lagoon and Po Delta are evenly distributed in the biplot showing a high heterogeneity and partially overlap, whereas the stations of the Comacchio Valleys and Pialassa della Baiona are clustered in the lower side of the biplot showing minor differences.

\section{Discussion}

Carbon concentrations in surface sediments showed a close relationship with sediment origin and the anthropogenic activities that affected the TWSs of the Northern Adriatic Sea. Indeed, in the northern basin of the Venice Lagoon, during the periods of the 16th and 17th centuries, the main rivers were diverted into the sea in order to avoid the landfill of the lagoon [32], and some of them enriched the sediments with high amounts of carbonates [17]. Inorganic carbon was transported and released into the lagoon by rivers Piave and Brenta originating from the Dolomites (i.e., the limestone mountain system located in the north-eastern Alps). The TWSs located southern of the Venice Lagoon instead were formed by the Adige and Po rivers originating in the central-western Alps and consist mainly of siliceous minerals. These different contributions of carbonates explain the decreasing concentrations of Cinorg and Ctot observed from North to South in the TWS in the western coasts of the North Adriatic Sea, as previously reported in a study [33] that described richer silicate-related elements in the sediments from the southern lagoon in comparison with the calcite/dolomite rich sediments of the northern lagoon.

Apart from this, the concentrations of the Corg seem to be affected mainly by the presence of macrophytes, the abundance of clams, and by clam-fishing activities. Notably, the presence of massive angiosperm meadows and macroalgal beds in Venice Lagoon enriched the sediments with organic matter $[34,35]$. To these should be added the considerable carbon sequestration rates of salt-marshes and reeds from freshwater flooded areas ( $\mathrm{psu}<9$ ) mainly colonized by Phragmites australis (Cav.) Trin. ex Steud. whose root-rhizome and stem fragments are still clearly recognizable in the peat deposits of the sediments alongside the landward area of the southern Venice Lagoon [36,37] and in the surrounding watershed lands [38]. These areas evolved over the last five centuries from palustrine reed/salt-marsh dominated environments toward depositional tidal-flat/subtidal environments storing 
elevated Corg concentrations in the sediments [36,37]. Despite the intense clam fishing activities in these areas, the high degree of confinement allowed the retention of the fine fraction resuspended preserving a higher carbon content in the superficial sediments. A similar reasoning can be developed for the Corg-rich areas of the Northern Lagoon near the mouth of the River Dese where reeds and salt-marshes are constantly evolving.

Instead, the other TWS are characterized by the absence of aquatic angiosperms that favor the sediment enrichment with organic matter. However, due to the lower dry density recorded in the

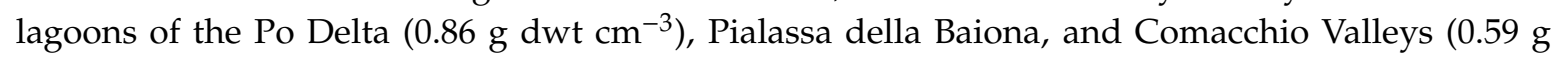
$\mathrm{dwt} \mathrm{cm}^{-3}$ ), the mean Corg concentrations in surface sediments resulted further reduced (Figure 2). However, Comacchio Valleys were completely deprived of vegetation, whereas the lagoons and ponds of the Po Delta, in spite of the high organic inputs from the Po river, were affected by anthropogenic activities. Indeed, in the latter TWSs, the availability of Corg was reduced both by (i) high concentration of clams (on average 3-6 $\mathrm{kg} \mathrm{m}^{-2}$ [7]) that filtered the organic matter present in the water column near the surface sediment, and (ii) sediment disturbance caused by clam-fishing with hydraulic and mechanical dredges, which mixed the first $10-15 \mathrm{~cm}$ of surface sediment releasing nutrients and organic matter in the water column [10]. The above-mentioned impacts are clearly observed by examining the data of carbon distribution obtained in the central basin of the Venice Lagoon, during different times: (a) 1987: The lagoon was dominated by a massive algal growth with a biomass ranging from 5 to $20 \mathrm{~kg}$ fwt $\mathrm{m}^{-2}$ in $65 \mathrm{~km}^{2}$ out of $132 \mathrm{~km}^{2}$ of the whole basin [35]); (b) 1993: Macroalgal biomass decreased from 4.78 to $0.69 \mathrm{~kg} \mathrm{~m}^{-2} \mathrm{fwt}[7,24,35]$; (c) 1998: Clam-fishing occurred in the entire central lagoon and the macroalgal biomass decreased further to $0.11 \mathrm{~kg} \mathrm{fwt} \mathrm{m}^{-2}$ with significant decrease of nutrient concentrations in surface sediments [10]; (d) 2003: Clam-fishing reached its excessive impact and lasted until 1999-2000 when clam production reached 40,000/60,000 tons $\mathrm{y}^{-1}$ [39]; (e) 2011: Clam-fishing declined to ca. 2000 tons $\mathrm{y}^{-1}$ and the lagoon showed a progressive ecological recovery [7]; (f) 2014: Aquatic angiosperms and macroalgae of high ecological value started to recolonize the lagoon [7]; and (g) 2018: The lagoon recovery continually increased and the aquatic angiosperm Ruppia cirrhosa, which disappeared in the open lagoon during the massive macroalgal development [40], started to re-colonize the choked areas.

In 1997, surface sediments of the central part of the Venice Lagoon showed the lowest dry density $\left(0.99 \mathrm{~g} \mathrm{~cm}^{-3}\right)$ and Corg was relatively high $\left(8.9 \mathrm{mg} \mathrm{cm}^{-3}\right)$ (Figure 5). In the following years, dry density progressively increased until $1.17 \mathrm{~g} \mathrm{~cm}^{-3}$, due to the loss of the fine fraction [41,42]. In 1998, Corg reached the minimum value $\left(5.9 \mathrm{mg} \mathrm{cm}^{-3}\right)$ when sediments were affected by intense clam-fishing activities [10,12,41] (Figure 5a). In 2003, Corg began to increase $\left(7.0 \mathrm{mg} \mathrm{cm}^{-3}\right.$, Figure 5a). In 2011, clam-fishing activities dropped significantly due to stock reduction and carbon concentrations consequently increased. In the subsequent years, Corg concentrations continuously increased due to lack of clams, the absence of sediment disturbance by clam-fishing activities, and the recolonization of macrophytes (mostly aquatic angiosperms and sensitive macroalgae) [7]. Eventually, either a high clam density or clam harvesting with sediment resuspension and fine fraction loss contributed significantly to Corg reduction as it was also recorded for the Po Delta lagoons, where the mean Corg concentration was $7.0 \mathrm{mg} \mathrm{cm}^{-3} \mathrm{dwt}$ (Figure 2) and where intense clam fishing activities are regularly carried out. Sediment resuspension promotes biodegradation of sedimentary organic matter [43]; moreover, the disruption of organic carbon distribution due to clam mechanical fishing activities was previously reported by [44] on a study of the immediate effects of mechanical clam harvesting. Indeed, the concentrations of Corg were strongly correlated to sediment fines percentage, whereas Cinorg was associated to sediment density and $\mathrm{pH}$ (Table 3). The positive correlation between Cinorg and $\mathrm{pH}$ (Table 3) may be explained by the reduction or disappearance of crustose coralline algae at low $\mathrm{pH}$ values $(6.7 \leq 8.0)$, and as a consequence, the loss of the sediment carbonate fraction, as previously described [45-47] for studies on volcanic marine $\mathrm{CO}_{2}$ vents in the sea around Ischia Island. Likewise, researchers [48] found that $\mathrm{pH}$ had a strong correlation with Cinorg produced from the small microcalcareus macroalgae belonging to the epiphytic genera Pneophyllum, Hydrolithon, and Melobesia, 
which grow on the largest macroalgae and aquatic angiosperms of the Italian TWS. These taxa, under an acidic water column $(\mathrm{pH}<7.93)$, were not able to grow, thus reducing significantly the production of carbonates trapped by these small algae and accumulated in surface sediments [48]. In extreme cases of acidic sediment ( $\mathrm{pH}<7.0$ ), as in the canals of the historical center of Venice, the shells of bivalves and gastropods are not present, as they dissolve rapidly. On the other hand, Corg showed a high affinity for Fine sediments, nutrients, [10] and pollutants [49-51], due to the larger surface area of smaller sediment particles. Therefore, in the case of the Po Delta lagoons the high filtration due to the abundance of clam populations and intense clam-fishing activities, resulted in the re-suspension of high amounts of sediments and the decrease of the organic matter rich fine fractions. This scenario significantly lowered the Corg concentrations, as recorded in the Venice Lagoon between the 1990s and 2010 [10,41,42].

Supplementary Materials: The following are available online at http://www.mdpi.com/2073-4441/12/12/3430/s1, Table S1: Carbon concentrations in the lagoons and ponds of the North Western Adriatic Sea; Table S2: Sediment density and carbon concentrations in the Venice Lagoon during different scenarios: 2002, 2011, 2014, 2018; Table S3, Mean sediment density and carbon concentrations in the central Venice Lagoon during different scenarios.

Author Contributions: Conceptualization, A.S., S.C., and M.M.; Formal analysis, A.B., Y.T., A.-S.J., M.G., C.G., and A.A.S; Funding acquisition, A.S.; Investigation, A.S.; Methodology, A.S. and S.C.; Supervision, A.S.; S.C., M.M., C.M., and A.A.S.; Visualization, A.S. and M.M.; Writing-original draft, A.S. and A.A.S.; Writing一review \& editing, A.S., A.A.S., and S.C. All authors have read and agreed to the published version of the manuscript.

Funding: This research was funded by Department funds.

Acknowledgments: The authors thank ARPA of Veneto and Emilia Romagna Regions, which financed the data collection of some measurement campaigns and the anonymous referees who contributed to the improvement of the paper.

Conflicts of Interest: The authors declare no conflict of interest.

\section{References}

1. Castaldelli, G.; Mantovani, S.; Welsh, D.T.; Rossi, R.; Mistri, M.; Fano, E.A. Impact of commercial clam harvesting on water column and sediment physicochemical characteristics and macrobenthic community structure in a lagoon (Sacca di Goro) of the Po River Delta. Chem. Ecol. 2003, 19, 161-171. [CrossRef]

2. Mistri, M.; Munari, C.; Pagnoni, A.; Chenet, T.; Pasti, L.; Cavazzini, A. Accumulation of trace metals in crayfish tissues: Is Procambarus clarkii a vector of pollutants in Po Delta inland waters? Eur. Zool. J. 2020, 87, 46-57. [CrossRef]

3. Velasco, J.; Lloret, J.; Millan, A.; Marin, A.; Barahona, J.; Abellan, P.; Sanchez-Fernandez, D. Nutrient and particulate inputs into the Mar Menor lagoon (SE Spain) from an intensive agricultural watershed. Water Air Soil Pollut. 2006, 176, 37-56. [CrossRef]

4. Sfriso, A.; Pavoni, B.; Marcomini, A.; Orio, A.A. Macroalgae, nutrient cycles and pollutants in the lagoon of Venice. Estuar. Coast. 1992, 15, 517-528. [CrossRef]

5. Kefford, B.; Dunlop, J.; Nugegoda1, D.; Choy, S. Understanding salinity thresholds in freshwater biodiversity, freshwater to saline transition. In Salt, Nutrient, Sediment and Interactions: Findings from the National River Contaminants Program; Land \& Water Australia: Canberra, Australia, 2007; Chapter 2; pp. 9-28.

6. Solidoro, C.; Bandelj, V.; Bernardi, F.A.; Camatti, E.; Ciavatta, S.; Cossarini, G.; Facca, C.; Franzoi, P.; Libralato, S.; Melaku Canu, D.; et al. Response of the Venice Lagoon Ecosystem to Natural and Anthropogenic Pressures over the last 50 years. In Coastal Lagoons-Critical Habitats of Environmental Change; Kennish, M.J., Paerl, H.W., Eds.; CRC Press: Boca Raton, FL, USA, 2010; Chapter 19; pp. 483-511.

7. Sfriso, A.; Buosi, A.; Mistri, M.; Munari, C.; Franzoi, P.; Sfriso, A.A. Long-term changes of the trophic status in transitional ecosystems of the northern Adriatic Sea, key parameters and future expectations: The lagoon of Venice as a study case. Nat. Conserv. 2019, 34, 193-215. [CrossRef]

8. Trozzi, C.; Vaccaro, R. Environmental impact of port activities. In Maritime Engineering and Ports II; Brebbia, C.A., Olivella, J., Eds.; WIT Press: Rome, Italy, 2000; pp. 151-161.

9. Bartoli, M.; Nizzoli, D.; Viaroli, P.; Turolla, E.; Castaldelli, G.; Fano, E.A.; Rossi, R. Impact of Tapes philippinarum farming on nutrient dynamics and benthic respiration in the Sacca di Goro. Hydrobiologia 2001, 455, $203-212$. [CrossRef] 
10. Sfriso, A.; Facca, C.; Ceoldo, S.; Silvestri, S.; Ghetti, P.F. Role of macroalgal biomass and clam fishing on spatial and temporal changes in $\mathrm{N}$ and $\mathrm{P}$ sedimentary pools in the central part of the Venice lagoon. Oceanol. Acta 2003, 26, 3-13. [CrossRef]

11. Sfriso, A.; Buosi, A.; Facca, C.; Sfriso, A.A. Role of environmental factors in affecting macrophyte dominance in transitional environments: The Italian Lagoons as a study case. Mar. Ecol. 2017, 38, e12414. [CrossRef]

12. Pranovi, F.; Da Ponte, F.; Torricelli, P. Historical changes in the structure and functioning of the benthic community in the lagoon of Venice. Estuar. Coast. Mar. Sci. 2008, 76, 753-764. [CrossRef]

13. Pitacco, V.; Mistri, M.; Aleffi, I.F.; Lardicci, C.; Prato, S.; Tagliapietra, D.; Munari, C. Spatial patterns of macrobenthic alpha and beta diversity at different scales in Italian transitional waters (central Mediterranean). Estuar. Coast. Mar. Sci. 2019, 222, 126-138. [CrossRef]

14. Scapin, L.; Zucchetta, M.; Sfriso, A.; Franzoi, P. Predicting the response of nekton assemblages to seagrass transplantations in the Venice lagoon: An approach to assess ecological restoration. Aquat. Conserv. Mar. Freshw. Ecosyst. 2019, 29, 849-864. [CrossRef]

15. Cavraro, F.; Bettoso, N.; Zucchetta, M.; D'Aietti, A.; Faresi, L.; Franzoi, P. Body condition in fish as a tool to detect the effects of anthropogenic pressures in transitional waters. Aquat. Ecol. 2019, 53, 21-35. [CrossRef]

16. Giordani-Soika, A.; Perin, G. L'inquinamento della laguna di Venezia: Studio delle modificazioni chimiche e del popolamento sottobasale dei sedimenti lagunari negli ultimi vent'anni. Boll. Mus. Civ. St. Nat. Venezia 1974, 26, 25-68.

17. Cossu, A.; De Fraja-Frangipane, E. Stato delle Conoscenze Sullo Inquinamento Della Laguna di Venezia. In Progetto Venezia, Ministero dei Lavori Pubblici, Magistrato alle Acque; Consorzio Venezia Nuova: Venezia, Italy, 1985; Volume 4.

18. Consorzio Venezia Nuova; Magistrato alle Acque. Nuovi Interventi per la Salvaguardia di Venezia. Rapporto sullo Stato Attuale dell'Ecosistema Lagunare; Studio 1.3.9: Rapporto Finale; Consorzio Venezia Nuova Venezia: Venezia, Italy, 1990; p. 361.

19. Gačić, M.; Mosquera, I.M.; Kovačević, V.; Mazzoldi, A.; Cardin, V.; Arena, F.; Gelsi, G. Temporal variations of water flow between the Venetian lagoon and the open sea. J. Mar. Syst. 2004, 51, 33-47. [CrossRef]

20. Masiol, M.; Facca, C.; Visin, F.; Sfriso, A.; Pavoni, B. Interannual heavy element and nutrient concentration trends in the top sediments of Venice Lagoon (Italy). Mar. Poll. Bull. 2014, 89, 49-58. [CrossRef]

21. Cucco, A.; Umgiesser, G. Modeling the Venice Lagoon residence time. Ecol. Model. 2006, 193, 34-51. [CrossRef]

22. Zuliani, A.; Zaggia, L.; Collavini, F.; Zonta, R. Freshwater discharge from the drainage basin to the Venice Lagoon (Italy). Environ. Int. 2005, 31, 929-938. [CrossRef]

23. Sfriso, A.; Pavoni, B.; Marcomini, A.; Orio, A.A. Annual variation of nutrients in the lagoon of Venice. Mar. Poll. Bull. 1988, 19, 54-60. [CrossRef]

24. Sfriso, A.; Marcomini, A. Decline of Ulva growth in the lagoon of Venice. Bioresour. Technol. 1996, 58, $299-307$. [CrossRef]

25. Sfriso, A.; Facca, C.; Bon, D.; Buosi, A. Macrophytes and ecological status assessment in the Po delta transitional systems, Adriatic Sea (Italy). Application of Macrophyte Quality Index (MaQI). Acta Adriat. 2016, 57, 209-226.

26. Munari, C.; Mistri, M. Ecological status assessment and response of benthic communities to environmental variability: The Valli di Comacchio (Italy) as a study case. Mar. Environ. Res. 2012, 81, 53-61. [CrossRef] [PubMed]

27. Sfriso, A.; Buosi, A.; Wolf, M.A.; Sfriso, A.A. Invasion of alien macroalgae in the Venice Lagoon, a pest or a resource? Aquat. Invasions 2020, 15, 245-270. [CrossRef]

28. Covelli, S.; Emili, A.; Acquavita, A.; Koron, N.; Fraganeli, J. Benthic biogeo-chemical cycling of mercury in two contaminated northern Adriatic coastal lagoons. Cont. Shelf Res. 2011, 31, 1777-1789. [CrossRef]

29. Schumacher, B.A. Method for the Determination of Total Organic Carbon (TOC) in Soil and Sediment; Ecological Risk Assessment Support Center, Office of Research and Development, US Environmental Protection Agency: Las Vegas, Nevada, 2002; pp. 1-2.

30. Kristensen, E.; Andersen, F.Ø. Determination of organic carbon in marine sediments: A comparison of two CHN analyzer methods. J. Exp. Mar. Biol. Ecol. 1987, 109, 15-23. [CrossRef]

31. Froelich, P.N. Analysis of organic carbon in marine sediments. Limnol. Oceanogr. 1980, 25, 564-572.

32. Miozzi, E. Venezia nei Secoli-La Laguna, Grafiche Trevisan, Castelfranco Veneto; Grafiche Trevisan, Castelfranco Veneto: Venice, Italy, 1968; Volume III, p. 543. 
33. Frignani, M.; National, I.; Dinelli, E. Composition of Venice Lagoon sediments: Distribution, sources, settings and recent evolution. GeoActa 2001, 1, 1-14.

34. Sfriso, A.; Marcomini, A.; Pavoni, B. Relationship between macroalgal biomass and nutrient concentrations in a hypertrophic area of the Venice lagoon. Mar. Environ. Res. 1987, 22, 297-312. [CrossRef]

35. Sfriso, A.; Facca, C. Distribution and production of macrophytes in the lagoon of Venice. Comparison of actual and past abundance. Hydrobiologia 2007, 577, 71-85. [CrossRef]

36. Roner, M.; D'Alpaos, A.; Ghinassi, M.; Marani, M.; Silvestri, S.; Franceschini, E.; Realdon, N. Spatial variation of salt-marsh organic and inorganic deposition and organic carbon accumulation: Inferences from the Venice lagoon, Italy. Adv. Water Resour. 2016, 93, 276-287. [CrossRef]

37. Roner, M.; Ghinassi, M.; Fedi, M.; Liccioli, L.; Bellucci, L.G.; Brivio, L.; D'Alpaos, A. Latest Holocene depositional history of the southern Venice Lagoon, Italy. Holocene 2017, 27, 1-14. [CrossRef]

38. Gambolati, G.; Putti, M.; Teatini, P.; Camporese, M.; Ferraris, S.; Gasparetto-Stori, G.; Nicoletti, V.; Silvestri, S.; Rizzetto, F.; Tosi, L. Peat Land Oxidation Enhances Subsidence in the Venice Watershed. Eos 2005, 86, $217-224$. [CrossRef]

39. Boscolo Brusà, R.; Cacciatore, F.; Ponis, E.; Molin, E.; Delaney, E. Clam culture in the Venice lagoon: Stock assessment of Manila clam (Venerupis philippinarum) populations at a nursery site and management proposals to increase clam farming sustainability. Aquat. Living Resour. 2013, 26, 1-10. [CrossRef]

40. Sfriso, A. Ruppia maritima L. e Ruppia cirrhosa (Petagna) Grande (Helobiae, Spermatophyta) in laguna di Venezia. Lavori Soc. Ven. Sc. Nat. 2008, 33, 41-46.

41. Sfriso, A.; Facca, C.; Marcomini, A. Sedimentation rates and erosion processes in the lagoon of Venice. Environ. Int. 2005, 31, 983-992. [PubMed]

42. Sfriso, A.; Facca, C.; Ceoldo, S.; Pessa, G. Sedimentation rates, erosive processes, grain-size and sediment density changes in the lagoon of Venice. In Scientific Research and Safeguarding of Venice. Corila Research Program 2003 Results; Campostrini, P., Ed.; Multigraf: Spinea, Italy, 2005; Volume 3, pp. 203-213.

43. Aller, R.C. Mobile deltaic and continental shelf muds as suboxic, fluidized bed reactors. Mar. Chem. 1998, 61, 143-155. [CrossRef]

44. Pranovi, F.; Da Ponte, F.; Raicevich, S.; Giovanardi, O. A multidisciplinary study of the immediate effects of mechanical clam harvesting in the Venice Lagoon. ICES J. Mar. Sci. 2004, 61, 43-52. [CrossRef]

45. Porzio, L.; Garrard, S.L.; Buia, M.C. The effect of ocean acidification on early algal colonization stages at natural $\mathrm{CO}_{2}$ vents. Mar. Biol. 2013, 160, 2247-2259. [CrossRef]

46. Kumar, A.; Abdelgawad,H.; Castellano, I.; Lorenti, M.; Delledonne, M.; Beemster, G.T.S.; Asard, H.; Buia, M.C.; Palumbo, A. Physiological and Biochemical Analyses Shed Light on the Response of Sargassum vulgare to Ocean Acidification at Different Time Scales. Front. Plant Sci. 2017, 8, 11-14. [CrossRef]

47. Foo, S.A.; Byrne, M.; Ricevuto, E.; Gambi, M.C. The carbon dioxide vents of Ischia, Italy, a natural System to assess impacts of ocean acidification on marine ecosystems: An overview of research and comparisons with other vent systems. Oceanogr. Mar. Biol. Annu. Rev. 2018, 56, 237-310.

48. Sfriso, A.; Buosi, A.; Wolf, M.A.; Sciuto, K.; Molinaroli, E.; Mistri, M.; Munari, C.; Moro, I.; Sfriso, A.A. Microcalcareus seaweeds a sentinel of trophic changes and $\mathrm{CO}_{2}$ trapping in transitional waters. Ecol. Indic. 2020, 118, 1-10. [CrossRef]

49. Pavoni, B.; Calvo, C.; Sfriso, A.; Orio, A.A. Time trend of PCB concentrations in surface sediment from a hypertrophic, macroalgae populated area of the lagoon of Venice. Sci. Total Environ. 1990, 91, 13-21. [CrossRef]

50. Secco, T.; Pellizzato, F.; Sfriso, A.; Pavoni, B. The changing state of contamination in the lagoon of Venice. Part 1. Organic pollutants. Chemosphere 2005, 58, 279-290. [CrossRef] [PubMed]

51. Bernardello, M.; Secco, T.; Pellizzato, F.; Chinellato, M.; Sfriso, A.; Pavoni, B. The changing state of contamination in the lagoon of Venice. Part 2: Heavy metals. Chemosphere 2006, 64, 1334-1345. [CrossRef] [PubMed]

Publisher's Note: MDPI stays neutral with regard to jurisdictional claims in published maps and institutional affiliations. 